\title{
BARAGWANATHIA BREVIFOLIOIDES, A NOMEN NOVUM FOR B. BREVIFOLIA P.KRAFT ET KVAČEK, 2017
}

\author{
PETR KRAFT ${ }^{1}$, †ZLATKO KVAČEK ${ }^{1}$ \\ ${ }^{1}$ Institute of Geology and Palaeontology, Faculty of Science, Charles University, Albertov 6, 12843 Prague 2, the Czech Republic; \\ e-mail:kraft@natur.cuni.cz.
}

Kraft, P., †Kvaček, Z. (2021): Baragwanathia brevifolioides, a nomen novum for B. brevifolia P.KRAFT et KvaČEK, 2017. - Fossil Imprint, 77(1): 53-54, Praha. ISSN 2533-4050 (print), ISSN 2533-4069 (on-line).

\begin{abstract}
Baragwanathia brevifolioides is established as a nomen novum for B. brevifolia P.KRAFT et KVAČEK, 2017, recently described from the Silurian of the Prague Basin, Czech Republic and revealed as a later homonym of $B$. brevifolia HuNDT, 1952.
\end{abstract}

Key words: nomenclature, Lycophyta, Baragwanathia, Silurian, Prague Basin, Thuringia

Received: January 16, 2021 | Accepted: June 16, 2021 | Issued: December 9, 2021

\section{Introduction}

Following our description of the new species Baragwanathia brevifolia P.KRAFT et KVAČEK, 2017, A. Doweld (pers. comm.) noticed that there is a nomenclatural error. The name was previously used by Hundt (1952) for a fossil remain from the upper Silurian black shale discovered in Thuringia, Germany. He provided an unclear formal description of the new species but requirements for recognition of a new name validity were achieved. He based the new species on a single specimen (Hundt 1952: 27, fig. 4), which represents a holotype (Turland et al. 2018: Art. 9.1). We tried to find that specimen in collections containing Hundt's material and use it for comparison, but its repository remains unknown to us. However, the specimen seems to be poorly preserved and its figure (Hundt 1952: fig. 4) is of low quality. Thus, no details can be recognized in the image, and even its determination as a plant fragment remains dubious. Regardless of the actual nature and taxonomic status of this specimen, Hundt's name remains valid as provided by the International Code of Nomenclature for algae, fungi, and plants (Turland et al. 2018: 54.1(a)). As a result, Baragwanathia brevifolia P.KRAFT et KVAČEK, 2017 is a later homonym of B. brevifolia Hund, 1952 (holotype: the specimen figured by Hundt (1952) in fig. 4, which was found at Ronneburg-Raitzhain in the lower Ludlow of Thuringia, Germany; its current repository is unknown). A replacement name for B. brevifolia P.KRAFT et KVAČEK, 2017 was established to rectify this inadmissible nomenclatural duplicity. The new name is different but derived from the earlier published epithet "brevifolia" to follow the original reference to the typical feature.

\section{Systematic palaeobotany}

Phylum Lycopodiophyta D.H. ScOTT, 1900

Class Lycopodiopsida BARTLING, 1830

Family Drepanophycaceae KräUSEL et WEYLAND, 1949

Genus Baragwanathia W.H.LANg et Cookson, 1935

Baragwanathia brevifolioides P.KRAFT et KVAČEK nom. nov. Text-fig. 1

Replaced synonym. Baragwanathia brevifolia P.KRAFT et KVAČEK, 2017, Gondwana Res., p. 183, figs 3A, $\mathrm{B}, \mathrm{D}, \mathrm{F}-\mathrm{J}, 4 \mathrm{~A}-\mathrm{C}$.

Holotype. KR 1, housed in the collection of the Czech Geological Survey, Prague, Czech Republic (figured in Kraft and Kvaček 2017: figs 3A, B, D, F-J, 4A-C and Text-fig. 1 here).

Plant Fossil Names Registry Number. PFN002239.

E t y m o log y. After short microphylls.

Type locality. Karlštejn - Ve Spáleném (near house no. 132), Czech Republic.

Ty p e h o r i z o n .PožáryFormation;Neocolonograptus ultimus Biozone; Přídolí, Silurian.

Diagn os is. Slender axes bearing subtle, linear and moderately long microphylls, uniform in dense arrangement, truncate or rounded at tips, showing a median midrib. Branching of stems isotomous. Apices of axes enfolded in a dense tuft of upward-facing microphylls (according to Kraft and Kvaček 2017: 183). 


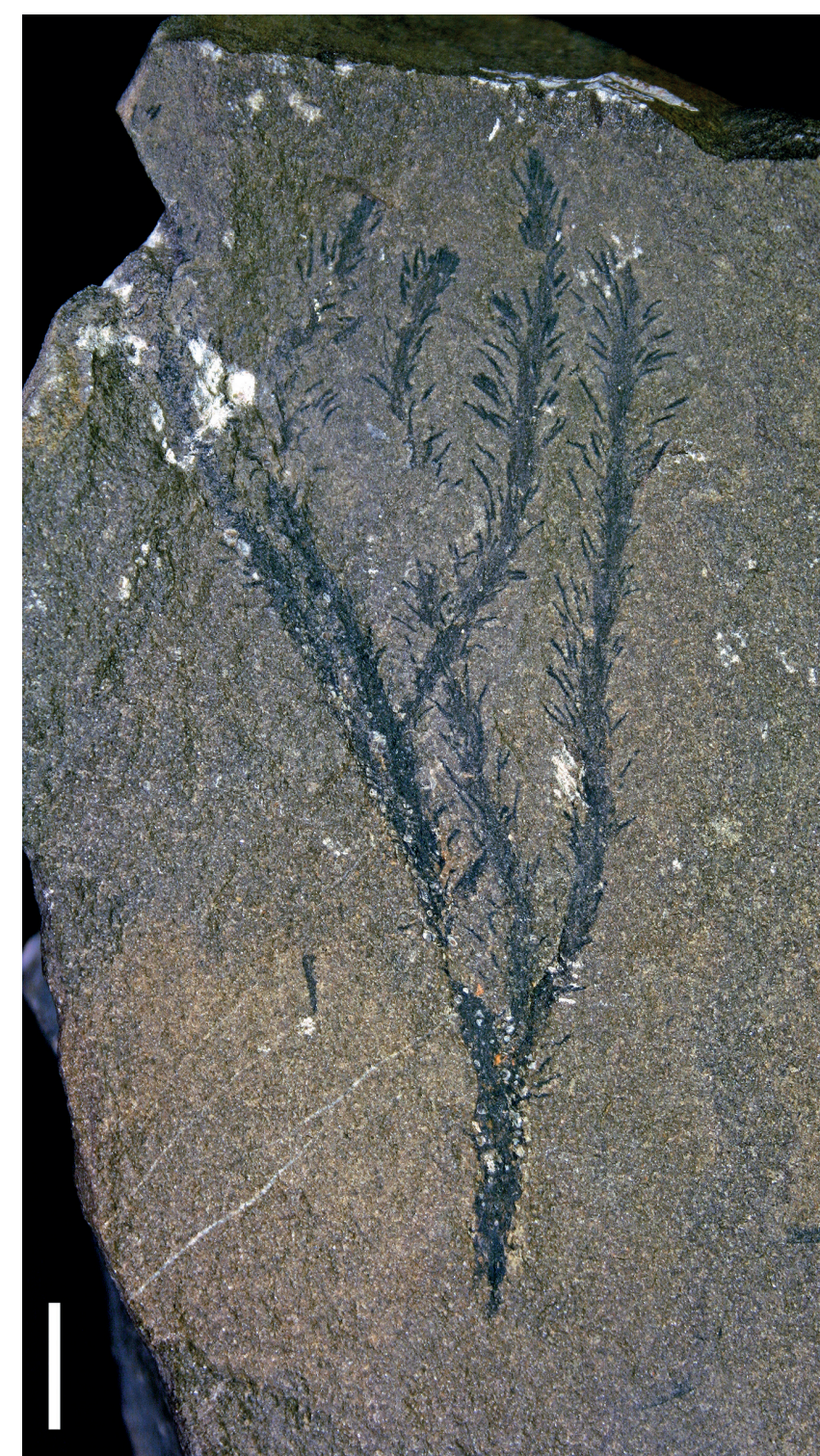

Text-fig. 1. Baragwanathia brevifolioides P.KRAFT et KvačEK nom. nov. Holotype (KR 1). Scale bar equals $10 \mathrm{~mm}$.

\section{Acknowledgements}

We are very grateful to Alexander B. Doweld (National Institute of Carpology, Moscow, Russia) for kindly notifying us of our nomenclatural error. We thank Jiří Kvaček and Jan Wagner (National Museum, Prague, Czech Republic) for their important comments and suggestions. Petr Daneš (National Museum, Prague, Czech Republic) kindly improved the quality of our English.

\section{References}

Hundt, R. (1952): Landpflanzreste (Psilophytales) aus dem tiefen Llandovery und Ludlow Ostthüringens. - Jahrbuch des Kreismuseums Hohenleuben-Reichenfels, 2: 25-29.

Kraft, P., Kvaček, Z. (2017): Where the lycophytes come from? - A piece of the story from the Silurian of peri-Gondwana. - Gondwana Research, 45: 180-190. https://doi.org/10.1016/j.gr.2017.02.001

Turland, N. J., Wiersema, J. H., Barrie, F. R., Greuter, W., Hawksworth, D. L., Herendeen, P. S., Knapp, S., Kusber, W.-H., Li, D.-Z., Marhold, K., May, T. W., McNeill, J., Monro, A. M., Prado, J., Price, M. J., Smith, G. F. (eds) (2018): International Code of Nomenclature for algae, fungi, and plants (Shenzhen Code) adopted by the Nineteenth International Botanical Congress Shenzhen, China, July 2017 (Regnum Vegetabile 159). - Koeltz Botanical Books, Glashütten, 254 pp. https://doi.org/10.12705/Code.2018 